\title{
Evaluation of Three Different Types Kshara Sutra Ligation in Arsha roga (Hemorrhoids)
}

\author{
Saxena Varsha ${ }^{1 *}$ and Singh Lakshman ${ }^{2}$ \\ 'Department of Shalya Tantra, Main Campus, Uttarakhand Ayurved University, Dehradun - 248001, \\ Uttarakhand, India; drvarshasaxena2015@gmail.com \\ 2Department of Shalya Tantra, Faculty of Ayurveda, Institute of Medical Sciences, \\ Banaras Hindu University, Varanasi - 221005, U.P., India; drlsingh@gmail.com
}

\section{Abstract}

Background: Anorectal disorders are a group of medical disorders that occur at perianal and the junction of the anal canal and the rectum. Arsha is enumerated under the heading of Ashtomahagada and occurs in Guda pradesh, the seat of Sadyapranahar marma. Out of available treatments of Arsha roga, the Kshara sutra ligation is the best one. In the present research work, three different types of Kshara Sutras, Snuhi (Euphorbia neriifolia), Guggulu (Commiphora mukul) and Udumber (Ficus racemosa) were used in Arsha roga (Hemorrhoids). Material and Methods: Total 33 patients of both genders of Arsha (Hemorrhoids) has been selected randomly after taking written consent and treated with three different types of Kshara Sutra followed in the "Anorectal clinic" of S.S. Hospital, IMS, BHU. Result: It reveals that lowest pain during the entire trial period was experienced by Group C - Udumber Kshara sutra with $81.8 \%$ and maximum pain was experienced by Group A - Snuhi Kshara sutra with $54.5 \%$. Lowest discharge was experienced by Group C- Udumber Kshara sutra with $72.7 \%$ and average healing time was minimum for group C - Udumber Kshara sutra (6.55 \pm 1.12 ) followed by group B - Guggulu Kshara sutra (7.18 \pm 1.16$)$. Maximum average healing time was seen in group A-Snuhi Kshara sutra (7.27 \pm 1.10$)$. Discussion: All types of Kshara sutra have good results in wound healing and prevent infection due to its alkaline $\mathrm{pH}(\mathrm{pH}-10.3)$ that works as antibacterial at site of ligation. Patients of hemorrhoids feel lowest pain during the entire trial period, minimum average healing time, fewer irritants and good tolerance by the patients by Group C - Udumber Kshara sutra and another study also favor this result.

Key words: Arsha Roga, Ayurveda, Hemorrhoids, Kshara Sutra Ligation

\section{Introduction}

Hemorrhoid is a common disorder, affecting $4 \%$ of the world population which is very specific to human race due to its erect posture. Classification of a hemorrhoid corresponds to its position relative to the dentate line. Internal hemorrhoids lie above the dentate line and are derived from endoderm whereas external hemorrhoid lies below the dentate line and derived from ectoderm ${ }^{1}$. Hemorrhoids are dealt rationally under the concept of Arsha roga. Acharya Charaka as well as Madhava mentioned that the Dushyas of Arsha are Twak, Mamsa and Medas ${ }^{2}$. According to Ayurveda the disease comes under the heading of Maharogas ${ }^{3}$. Arsha occurs in Gudabhaga, which is undoubtedly a Marma, and it is well known for its chronicity and difficult to treat. If neglected or not cured properly, it may turn into complications such as hemorrhage, thrombosis, portal pyaemia, fibrosis, strangulation, suppuration. Acharya Sushruta has mentioned four lines of management such as: Bhaisaja, Kshara, Agni, Shastra ${ }^{4}$. According to Acharya Vagbhatta, Arsha is a muscular projection (Mans-kila) which troubles the patient like an enemy ${ }^{5}$ and Acharya Madhava also followed it $^{6}$. Internal hemorrhoids are classified by the degree of prolapse of the anal canal. External may be classified as acute (hemorrhoidal 
thrombosis) or chronic (anal skin tags). In modern surgery for treatment of hemorrhoids sclerotherapy, infrared, photocoagulation, rubber band ligation laser therapy, Lord's dilatation, hemorrhoidectomy, and stapled hemorrhoidectomy are in practice but these are costly and chance or recurrence is more. Conventional kshara sutra therapy yield better long-term results and chance of recurrence is very less. This clinical research work explores effect of three different type Kshara sutras ligation in Arsha roga (hemorrhoids).

\subsection{Kshara Sutra in Arsha Roga}

The ancient writing of Indian medical practitioners like Sushruta, Charaka and Vagbhatta provide an elaborate description of Arsha Roga and various modalities of treatment along with brief description of Kshara sutra therapy. Complete and detail descriptions of Kshara sutra are not available in Sushruta Samhita. Acharya Sushruta (800 BC) has described four folded line of treatment as Bhaishaja chikitsa, Kshara karma, Agni karma and Shastra Karma in management of anorectal disorders ${ }^{7}$. Among all these therapies Kshara karma has become very useful and recently modified method of treatment for selected anorectal diseases. Kshara sutra has been described in most of the ancient books of Ayurveda as medicated thread. Kshara sutra has extensive uses in a number of surgical disorders which often pose problems for the patients and also for the surgeons. This has specific role to play in the common anorectal conditions like hemorrhoids, fistula and fissures etc. Recent modern surgical texts are also accepting the role of Kshara sutra in the management of Anorectal disorders. The present form of Kshara Sutra therapy was initiated by Dr. P. S. Shankaran and subsequently established by Prof. P. J. Deshpandey through many researches and development in department of Shalya Tantra at Banaras Hindu University. The process of development was supported in last few decades by eminent scholars like Prof. K. R. Sharma, Prof. G. C. Prasad, Prof. S. N. Pathak and others from same department ${ }^{8}$. Now Kshara Sutra therapy has been accepted globally and has emerged as a gold standard treatment for Anorectal diseases ${ }^{9}$. The Indian Council of Medical Research (ICMR) has validated this unique and effective approach ${ }^{10}$.

\section{Materials and Methods}

\subsection{Study Design}

In the present study three types of Kshara sutra: Snuhi kshara sutra, Guggulu Kshara sutra and Udumber Kshara sutra have been prepared and evaluated clinically on the patients of Arsha roga (Hemorrhoids).

\subsection{Place of Study}

Shalya OPD \& I.P.D, S.S. Hospital, Institute of Medical Sciences, Banaras Hindu University, Varanasi.

\subsection{Selection of the Patient}

33 patients of both genders suffering from Arsha (Hemorrhoids) has been selected randomly after taking written consent. All selected cases were suffering from internal hemorrhoids.

\subsection{Ethical Clearance}

The study was approved by the ethical committee of IMS, BHU vide letter no. Dean/2011-2012/EC/296, dated 01.11.2011.

\subsection{Inclusion Criteria}

Patients diagnosed to have Prolapsed rectum and those unwilling for surgery are randomly included in the study irrespective of age, sex, chronicity, Prakriti and type of disease.

\subsection{Exclusion Criteria}

Anemic pt. $(\mathrm{Hb}<9$ gram \%), Malnourish patient, Bleeding disorder, Uncontrolled diabetes mellitus, Tubercular patient, Pregnancy, Malignancy suggested by biopsy, HIV positive patient, HBsAg positive patient.

\subsection{Grouping and Design}

11 patients of Arsha roga (Hemorrhoids) were taken in each groups of Kshara sutra (Table 1).

\section{Preparation of Three Different Types of Kshara Sutra}

\subsection{Snuhi Kshara Sutra}

The Barbour thread no. 20 has been spread throughout the length and breadth of the hanger which is then 
Table 1. Experimental design

\begin{tabular}{|c|c|c|c|}
\hline Group & Group A & Group B & Group C \\
\hline \multirow{5}{*}{ 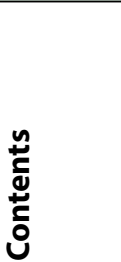 } & Snuhi Kshara sutra & Guggulu Kshara sutra & Udumber latex Kshara sutra \\
\hline & Barbour Thread no 20 & Barbour Thread no 20 & Barbour Thread no 20 \\
\hline & Snuhi kshira & Guggulu extract & Udumber latex \\
\hline & Apamarga Kshara & Apamarga Kshara & $\ldots \ldots \ldots \ldots \ldots$ \\
\hline & Haridra powder & Haridra powder & n............... \\
\hline
\end{tabular}

mounted over a hanger stand. Each hanger is then smeared with Snuhi Ksheer or latex with the help of clean gauze piece soaked in latex. The hanger was then replaced into the cabinet in order to dry the threads. The same process was repeated the next day. Eleven such coatings with Snuhi Kshara alone were accomplished. The $12^{\text {th }}$ coating was done by first smearing the thread with latex and then passing the wet thread through a heap of finely powdered Kshara. When all the threads were smeared with Kshara, the hanger was gently shaken so that all the excess particles of Kshara fall down. It was again placed into the cabinet for drying. This process was repeated till seven coatings of Snuhi Ksheer and Kshara were achieved, thus the total number of coatings being 18 . The remaining three coatings were finally completed with the latex of Snuhi and the fine powder of turmeric in the same way. Thus, twenty one coatings over the thread were completed. When all the 21 coatings were completed, each thread measuring about $30-31 \mathrm{~cm}$ was cut away from the hanger and sealed in a glass tube.

The orders of 21 coatings are as:

- Snuhi Kshara = 11

- Snuhi Kshara + Kshara $=7$

- Snuhi Kshara + Haridra $=3$

\subsection{Guggulu Kshara Sutra}

Similarly Guggulu Kshara sutra was prepared.

- Guggulu resin dissolved in ethyl alcohol $=11$

- Guggulu resin + Kshara $=7$

- Guggulu resin + Haridra $=3$

\subsection{Udumber Latex Kshara Sutra}

For Udumber latex Kshara sutra only 11 coatings of Udumber Ksheer is coated.
- Udumber Kshara = 11

When dried the last coating, each thread removed from the hanger, kept in a sterile tube which is gently sealed and stored in an incubator at $37^{\circ} \mathrm{C}$. By doing so, Kshara sutra did not get contaminated inspite of passage of time, indicating that the ingredients do not allow the growth of bacteria even over longer periods of time.

\section{Investigations}

- Blood: Hb\%, TLC, DLC, ESR, FBS, PPBS, CT, BT, Blood urea, S. Creatinine

- Urine: Routine and microscopy

- Stool: Ova and Cyst; occult blood.

- HIV \& HBsAg

- Chest X-Ray, ECG: as and when required.

\section{Method of Kshara sutra Application}

\subsection{Preoperative Procedure}

- Well written inform consent of patient was taken.

- Cleaning of bowel was done at prior night.

- Part preparation of the perianal area was done.

- Xylocaine sensitivity to be done.

- Inj. T.T $0.5 \mathrm{ml}$ was given by I.M. route.

\subsection{Operative Procedure}

Patient was kept in lithotomy position on operation table. The part is cleaned with aseptic solutions and then after local anesthesia is given with $1 \%$ xylocaine injection under the advice of anesthetics and draping was done. Later on position of various pile masses were assessed. The pile mass was hold with the help of pile holding forceps. Then the slight pull is exerted over the 
pile mass, so that its base is clearly demarcated along with the blood vessels.

\subsection{Transfixation}

Pile mass has been transfixed by passing the curved round body needle with Kshara sutra at its base. The transfixation was made horizontally or vertically according to the suitable position of hemorrhoid mass, preferably horizontal then stab cut is made on the budge of transfixed hemorrhoid mass to prevent strangulation. Then warm water irrigation was done following to $\mathrm{T}$ bandaging (Figure 1).

\subsection{Post Kshara sutra Regime}

The patient was advised to have sitz bath (Luke warm water) twice a day. Ambulation of the patients was made as a routine to encourage all the patients to remain as active as possible and to lead a normal life. The patients were advised to take easily digestible diet along with adjuvant therapies if required.

\subsection{Follow-up of the Patient}

The patients of hemorrhoids were asked to attend the OPD on days 1, 3, 7, 15, 30 after Kshara Sutra ligation, then every fortnightly for 3 months then monthly till six month.

\section{Assessment Criteria}

The patients of Arsha roga (Hemorrhoids) were assessed on the basis of subjective and objective parameters such as Pain, Discharge, Bleeding and Sphincter tone. The total information of subjective or objective assessment

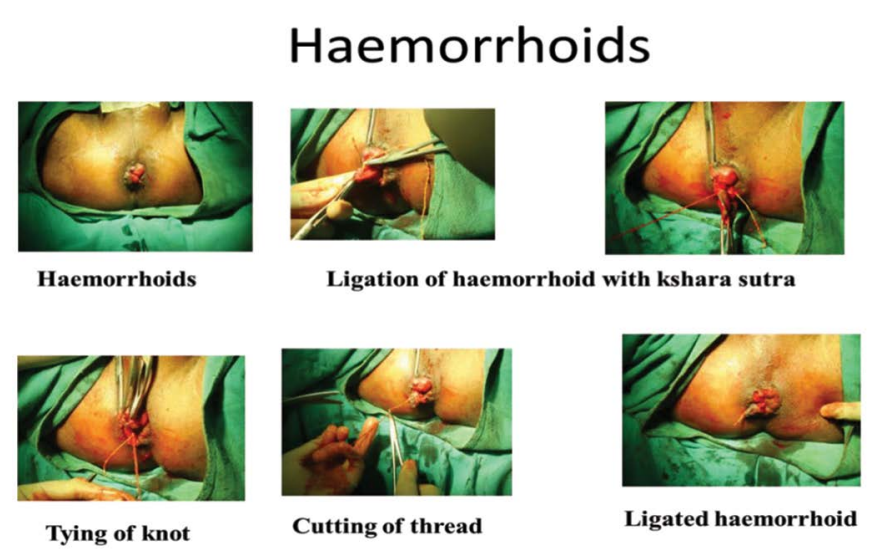

pre-operatively or post-operatively has been done in a systemic and scientific manner on regular weekly information. The treatment effect has assessed on the basis of the relief of signs and symptoms of the major symptoms of the disease (Table 2-6).

\subsection{Subjective Parameter}

The patients were assessed on the basis of following parameters before and after treatment as follows:

\subsubsection{Pain on VAS (Visual Analogue Scale)}

Pain was recorded on Visual Analog Scale on days 1, 3, 7, 15 and 30 after operation.

\subsubsection{Grading of Discharge}

Grading of discharge amount was based on this table.

\subsubsection{Post-Operative Bleeding Per Rectum}

Recorded on days $1,3,7,15,30$ postoperatively

\subsubsection{Grading of Sphincter Tone}

Grading of sphincter Tone was based on this table

\section{Objective Parameters}

\subsection{Complete Healing Time}

Complete healing time is the total time taken for the entire treatment. This is recorded in the patients who are on the follow up regimen. The patients of hemorrhoids were asked to attend the OPD on days 1,3,7,15,30 after Kshara Sutra ligation, then every fortnightly for 3 months then monthly till six month.

\subsection{Pain Relief Day (P.R.D.)}

This is the day when the patient is totally relieves or free from post-operative pain. Due to irritation effect of Kshara on the local tissue there will be burning and scalding type of pain often encountered. However the pain is relieved after dissolving of the Kshara generally after $3^{\text {rd }}$ or $4^{\text {th }}$ day in different conditions. The $\mathrm{pH}$ value of Kshara sutra and type of tissue probably effect the reaction. Therefore in this study it is recorded as the pain relief day i.e. (P.R.D.).

Figure 1. Method of Kshara sutra application. 
Table 2. Subjective and Objective parameters for assessment

\begin{tabular}{ll}
\hline Subjective Parameter & Objective Parameters \\
\hline Pain by VAS (VAS Analogue Scale) & Complete healing time \\
Grading of discharge & Pain relief day (P.R.D.) \\
Post-operative bleeding per rectum & Time taken for sloughing out of hemorrhoid masses (in days) \\
Grading of sphincter Tone & Serial photography. \\
\hline
\end{tabular}

Table 3. Visual Analogue Scale ${ }^{11}$

\begin{tabular}{llll}
\hline Grade & Mark & Pain & Explanation \\
\hline 0 & 0 mark & No & Absence of pain/ no pain. \\
1 & $1-3$ mark & Mild & Mild pain that can be easily ignored. \\
2 & $4-6$ mark & Moderate & Moderate pain that cannot be ignored and needs treatment. \\
3 & $7-10$ mark: & Severe & Severe pain which needs constant attention. \\
\hline
\end{tabular}

Table 4. Grading of Discharge ${ }^{12}$

\begin{tabular}{lll}
\hline Grade & Discharge & Explanation \\
\hline 0 & No & No discharge/dry dressing \\
1 & Mild & Patient requires changing up to 1 pad of $4 \times 4 \mathrm{~cm}$ gauze. \\
2 & Moderate & Patient requires changing up to two pad of $4 \times 4 \mathrm{~cm}$ gauze. \\
3 & Severe & Patient requires changing more than two pad of $4 \times 4 \mathrm{~cm}$ gauze. \\
\hline
\end{tabular}

Table 5. Grading of post-operative bleeding per rectum

\begin{tabular}{lll}
\hline Grade & Bleeding per rectum & Explanation \\
\hline 0 & No & No bleeding. \\
1 & Mild & Patient requires change up to 1 pad of $4 \times 4 \mathrm{~cm}$ gauze. \\
2 & Moderate & Patient requires change up to two pad of $4 \times 4 \mathrm{~cm}$ gauze. \\
3 & Severe & Patient requires change more than two pad of $4 \times 4 \mathrm{~cm}$ gauze. \\
\hline
\end{tabular}

Table 6. Grading of sphincter tone ${ }^{13}$

\begin{tabular}{ll}
\hline Grade & Explanation (DRESS) \\
\hline 0 & No discernable pressure at anus \\
1 & Loose \\
2 & Slightly loose \\
3 & Normal \\
4 & Tight \\
5 & Extremely tight \\
\hline
\end{tabular}

\section{Results and Observations}

\subsection{Postoperative Pain}

It reveals that in the patients of hemorrhoids, the lowest pain during the entire trial period was experienced by Group C - Udumber Kshara sutra with $81.8 \%$ were experienced no pain on $5^{\text {th }}$ Postoperative day followed by Group B - Guggulu Kshara sutra with $63.6 \%$ were experienced no pain on $5^{\text {th }}$ Postoperative day, Whereas 
maximum pain was experienced by Group A - Snuhi Kshara sutra with only $54.5 \%$ were experienced no pain on $5^{\text {th }}$ Postoperative Day. Pain was seen maximum immediately after Kshara sutra ligation (Table 7).

\subsection{Postoperative Discharge}

It reveals that in the patients of hemorrhoids, the lowest Discharge during the entire trial period was experienced by Group C - Udumber Kshara sutra with $72.7 \%$ and Group B - Guggulu Kshara sutra with $72.7 \%$ patients reported complete relief from any type of discharge on $5^{\text {th }}$ Postoperative day, Whereas higher Discharge was experienced by Group A - Snuhi Kshara sutra with 63.6 $\%$ patients reported complete relief from any type of discharge on $5^{\text {th }}$ Postoperative Day. It was observed that sloughing and serous discharge was present in all type of Kshara sutra ligation varing from $2^{\text {nd }}$ to $7^{\text {th }}$ Postoperative day but in group A - Snuhi Kshara sutra, it was found that the discharge from anus was more number which may lead anal infection and wound contamination due to fecal matter. However there was $45.5 \%$ patients experienced purulent discharge in group A, while only $27.3 \%$ patients experienced purulent discharge in group B and group C. The purulent discharge found in less number of cases in group $\mathrm{C} \&$ group $\mathrm{B}$ proving its advantages over the group A (Table 7).

\subsection{Postoperative Hemorrhage}

It reveals that in the patients of hemorrhoids, the lowest Bleeding during the entire trial period was experienced by Group C - Udumber Kshara sutra with 90.0\% patients reported complete relief from bleeding on $5^{\text {th }}$ Postoperative day, followed by Group A - Snuhi Kshara sutra with $81.8 \%$ and Group B - Guggulu Kshara sutra with $81.8 \%$ patients reported complete relief from bleeding on $5^{\text {th }}$ Postoperative Day (Table 7).

It was seen that average sloughing off was minimum for group A $(3.27 \pm 0.10)$ followed by group B $(4.39 \pm 0.3$ 0 ). Maximum average sloughing off was seen in group $C$ $(5.07 \pm 0.16)$. But it was seen that average healing time was minimum for group C - Udumber Kshara sutra (6.55 \pm 1.12 ) followed by group B - Guggulu Kshara sutra (7.18 $\pm 1.16)$. Maximum average healing time was seen in group A- Snuhi Kshara sutra $(7.27 \pm 1.10)$. According to

Table 7. Comparison between pain, discharge and bleeding

\begin{tabular}{|c|c|c|c|c|c|c|c|c|}
\hline \multirow[t]{2}{*}{ Symptoms } & \multicolumn{8}{|c|}{ Between the group comparison Wilcoxon Signed Ranks test } \\
\hline & Group & & Mean & $\begin{array}{c}\text { Std. } \\
\text { Deviation }\end{array}$ & $\%$ Relief & Z & p-value & Significant \\
\hline \multirow[t]{6}{*}{ Pain } & Group A & F0 & 2.45 & 0.522 & 54.5 & $Z=2.976$ & $p=0.003$ & HS \\
\hline & & $\mathrm{F} 4$ & 0.45 & 0.522 & & & & \\
\hline & Group B & Fo & 2.27 & 0.786 & 63.6 & $Z=2.994$ & $p=0.003$ & HS \\
\hline & & $\mathrm{F} 4$ & 0.36 & 0.505 & & & & \\
\hline & Group C & F0 & 2.09 & 0.831 & 81.8 & $Z=2.980$ & $p=0.003$ & $\mathrm{HS}$ \\
\hline & & F4 & 0.18 & 0.405 & & & & \\
\hline \multirow[t]{6}{*}{ Discharge } & Group A & F0 & 1.55 & 1.036 & 63.6 & $Z=2.565$ & $p=0.010$ & $S$ \\
\hline & & F4 & 0.36 & 0.505 & & & & \\
\hline & Group B & F0 & 1.55 & 0.820 & 72.7 & $Z=2.913$ & $p=0.004$ & $\mathrm{HS}$ \\
\hline & & F4 & 0.27 & 0.467 & & & & \\
\hline & Group C & F0 & 2.50 & 0.527 & 72.7 & $Z=2.842$ & $p=0.004$ & $\mathrm{HS}$ \\
\hline & & F4 & 0.30 & 0.483 & & & & \\
\hline \multirow[t]{6}{*}{ Bleeding } & Group A & Fo & 1.45 & 1.128 & 81.8 & $Z=2.640$ & $p=0.008$ & $\mathrm{HS}$ \\
\hline & & F4 & 0.27 & 0.467 & & & & \\
\hline & Group B & Fo & 1.09 & 1.044 & 81.8 & $Z=2.271$ & $p=0.023$ & $S$ \\
\hline & & $\mathrm{F} 4$ & 0.36 & 0.505 & & & & \\
\hline & Group C & F0 & 1.82 & 0.874 & 90.9 & $Z=2.850$ & $p=0.004$ & $\mathrm{HS}$ \\
\hline & & F4 & 0.18 & 0.405 & & & & \\
\hline
\end{tabular}


One way ANOVA test applied for comparison between the groups $A, B, C$, result is non-significant with $p>0.05$ (Table 8; Figure 2).

\section{Discussion}

Anorectal disorders are very common among all ages. Hemorrhoids (Arsha) are one of the most common ano rectal diseases in which varicosity of haemorrhoidal vein occurs, may be internal or external. It is manifested due to improper diet, prolonged standing and faulty habits of defecation causing derangement of tridosha, mainly Vata dosha. Hemorrhoids have many distressing symptom such as pain, bleeding, prolapsed piles, discharge per anum, its treatment is targeted at elimination of symptoms, improvement of quality of life and patient satisfaction. Many studies prove that Kshara sutra ligation show better result on many parameters as compared other treatment modalities as rubber band ligation etc. in the parameter of patient satisfaction, Time taken for sloughing off of hemorrhoidal masses, Return to day to day activities; Postoperative pain and hospital stay Kshara sutra ligation is better than any modern therapy

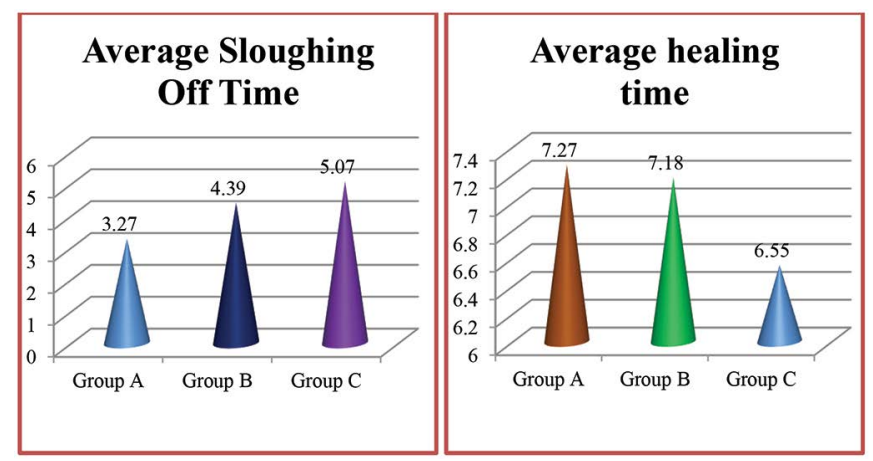

Figure 2. Comparison between times taken for Sloughing off of the mass \& Average healing time for hemorrhoid such as rubber band ligation etc ${ }^{14}$. All type of Kshara sutra have good result in wound healing and prevent infection due to its alkaline $\mathrm{pH}(\mathrm{pH}-10.3)$ that works as antibacterial at site of ligation ${ }^{15}$. In this research work patients of hemorrhoids feel lowest pain during the entire trial period, minimum average healing time, fewer irritants and good tolerance by the patients by Group C - Udumber Kshara sutra and another study also favor this result ${ }^{16}$. Kshara sutra ligation creates pressure effect that cause mechanical strangulation of the blood vessels and tissue and, ultimately, forces falling out of the pile mass during defecation ${ }^{17}$. The Guggulu Kshara sutras have minimum post-operative discharge and minimum average healing time due to its antiinflammatory, antibacterial property which helped in wound healing ${ }^{18,19}$.

\section{Conclusion}

Kshara sutra therapy is a radical cure in the treatment of Hemorrhoids (Arsha) without complications and recurrence. Post-operative pain was lowest experienced by Udumber Kshara sutra after that Guggulu Kshara sutra and maximum pain was experienced by Snuhi Kshara sutra. Post-operative discharge was lowest experienced by Udumber Kshara sutra after that Guggulu Kshara sutra whereas higher discharge was experienced by Snuhi Kshara sutra. Post-operative hemorrhage was lowest experienced by Udumber Kshara sutra followed by Snuhi Kshara sutra and Guggulu Kshara sutra. Average healing time was minimum for Udumber Kshara sutra followed by Guggulu Kshara sutra and maximum average healing time was seen Snuhi Kshara sutra. There was no adverse effect of any of the drugs observed during the course of study.

Table 8. Comparison between times taken for Sloughing off of the mass \& Average healing time

\begin{tabular}{llc}
\hline Groups & Average sloughing off time & Average healing time \\
\cline { 2 - 3 } & & Mean \pm SD \\
\hline Group A (Snuhi Kshara sutra) & $3.27 \pm 0.10$ & $7.27 \pm 1.10$ \\
Group B (Guggulu Kshara sutra) & $4.39 \pm 0.30$ & $7.18 \pm 1.16$ \\
Group C (Udumber latex Kshara sutra) & $5.07 \pm 0.16$ & $6.55 \pm 1.12$ \\
Between the group comparison & $\mathrm{F}=1.936$ & $\mathrm{~F}=1.344$ \\
One way ANOVA Test & $\mathrm{p}=0.162$ & $\mathrm{p}=0.276$ \\
& $\mathrm{NS}$ & $\mathrm{NS}$ \\
\hline
\end{tabular}




\section{Source of Support:}

Nil

\section{Conflict of Interest:}

None Declared

\section{References}

1. Zhifei Sun, John Migal. Review of Hemorrhoid Disease: Presentation and Management. Clinics in Colon and Rectal Surgery. 2016 Mar; 29(1):22-9. Doi: 10.1055/s0035-1568144 https://doi.org/10.1055/s-0035-1568144 PMid:26929748 PMCid:PMC4755769

2. Agnivesha. Charaka Samhita, English translation by Sharma RK, Dash B. Vol-II, Chikitsa Sthan (14/6), Chaukhambha Sanskrit series office, Varanasi. 2010.

3. Sushruta. Sushruta samhita, English translation by Sharma P.V, Vol I, Sutra sthana 33/4-5, Chaukhambha Vishvabharati, Varanasi. 2005.

4. Sushruta. Sushruta samhita, English translation by Sharma P.V, Vol II, Chikitsa sthana 6/3, Chaukhambha Vishvabharati, Varanasi. 2005.

5. Vagbhata. Astanga Hriday, English translation by Srikantha Murty KR, Vol-II, Nidana sthana (7:1), Chaukhambha, Krishnadas Academy Varanasi. 2015.

6. Madhava Nidana of Sri Madhavakara with the "Madhukosha" Sanskrit Commentary by Sri Vijayarakshita Madhukosh Tika 1/5. Chaukhambha Sanskrit Sansthan, Varanasi.

7. Panigrahi HK, Rani R, Padhi MM, Lavekar GS. Clinical Evaluation of Kshara sutra therapy in the management of Bhagandara (Fistula-in-Ano)- A prospective study. Ancient Science of Life. 2009;28(3):29-35. PMid:22557318 PMCid:PMC3336315

8. Saxena V, Singh L. A Comparative Study of Three Different Types of Kshara Sutras in the Management of Bhagandara (Fistula in Ano). International Journal of Ayurveda \& Medical Sciences. 2017; 2(3):54-8.

9. Sahu M. A Manual on Fistula in Ano and Ksharasutra therapy. First edition published by National resource: Centre on Ksharsutra therapy 2015. 2015; 1(1).

10. Multicentric randomized controlled clinical trial of Ksharasutra (Ayurvedic medicated thread) in the management of fistula-in-ano. Indian Council of Medical Research. The Indian Journal of Medical Research. 1991 Jun; 94:177-85.

11. Sarkar PK, Ballantyne S: Management of leg ulcers. Postgraduate Medical Journal. 2000; 76:674-82. https://doi.org/10.1136/pmj.76.901.674 PMid:11060140 PMCid:PMC1741806

12. Copper D. The physiology of wound healing: An Overview in Chronic Wound care. Wayne, PA: Health Management publications. 1990; p. 1-11.

13. Orkin Bruce A, Sinykin Svethana B. Lloyd P C DRESS. LWW Journal American society of Colon \& Rectal Surgeon. 2010 Dec; 53(12):1656-60.

14. Rakhi Singh, Ramesh C Arya, Satinder S Minhas and Anil Dutt. A comparative study of Barron's rubber band ligation with Kshar Sutra ligation in hemorrhoids. International Journal of Ayurveda Research. 2010 Apr-Jun; 1(2):73-81. Doi: 10.4103/0974-7788.64407

15. Kohli K, Ali J, Ansari MJ, Raheman Z. Curcumin: A natural anti-inflammatory agent. Indian Journal of Pharmacology. 2005; 37(3):141-7. https://doi. org/10.4103/0253-7613.16209

16. Manju Rani, Riju Agarwal, Sijjoria KK. Preparation of different types of Kshara sutra. International Journal of Research in Ayurveda and Pharmacy. 2016 Mar-Apr; 7(Suppl 2):176-80. http://dx.doi.org/10.7897/22774343.07281

17. Meva Lal Gupta SK. Gupta and Chaturbhuja Bhuyan: Comparative clinical evaluation of Kshara Sutra ligation and hemorrhoidectomy in Arsha (hemorrhoids); Ayu. 2011 Apr-Jun; 32(2):225-9. Doi: 10.4103/0974-8520.92591. https://doi.org/10.4103/0974-8520.92591 PMid:22408307 PMCid:PMC3296345

18. Arora RB, Kapoor V, Gupta SK and Sharma RC. Isolation of a crystalline steroidal compound from Commiphora mukul \& its anti-inflammatory activity. Indian Journal of Experimental Biology. 1971; 9(3):4034. PMid:5144347

19. Saeed MA and Sabir AW. Antibacterial activities of some constituents from oleo-gum-resin of Commiphora mukul. Fitoterapia. 2004; 75(2):204-8. https://doi.org/10.1016/j. fitote.2003.12.003 PMid:15030926 